\title{
INTEGRASI DAN ASIMETRI HARGA KARET TSR20 INDONESIA DENGAN HARGA TSR20 DUNIA
}

\section{INTEGRATION AND ASYMMETRY OF TSR20 INDONESIA RUBBER PRICE AT WORLD TSR20 PRICE}

\author{
Andi Suryadi*), Sahara**), dan Rokhani Hasbullah***) \\ *) PT. Bintang Dharma Hurip \\ Golden Plaza G 43 - G 44 Lt 1, Jl RS Fatmawati No.15 12150 \\ **) Departemen Ilmu Ekonomi, Fakultas Ekonomi dan Manajemen, Institut Pertanian Bogor \\ Jl. Agatis Kampus IPB Darmaga, Bogor 16680 \\ ${ }^{* * *}$ Departemen Teknik Mesin dan Biosistem, Fakultas Teknologi Pertanian, Institut Pertanian Bogor \\ Jl. Lingkar Akademik, Babakan, Dramaga, Bogor, Jawa Barat 16680
}

\begin{abstract}
This study aims to determine the relationship of integration and asymmetry between TSR20 rubber price in Indonesian market, SICOM and New York. The scope of this research uses Asymmetric Error Corrections Model (AECM) method. The asymmetry analysis is an asymmetry speed of adjustment. The data used were monthly time series, from 2010 until 2016. The result of the research shows that all of markets have been integrated. The relationship is that the SICOM market affected the Indonesian market, SICOM market and New York market as well as the Indonesian market with the New York market is mutually influential. As for the asymmetric relationship, it's seen that there was asymmetry relationship in the short term between SICOM and the Indonesian market and also symmetry in long-term relationship. In the relationship between the market of Indonesia and New York market, symmetry occurs in the short term but in the long term it is not asymmetry. Meanwhile the relationship between SICOM market and New York market, there are symmetries both in short term and in long term. The next recommendation research is, besides seeing the price in the SICOM market and United States market, it is important also to see the integrated price in China market. China market recently became a market which importing many natural rubbers besides the United States and Japan.
\end{abstract}

Keywords: TSR20, asymetri, SICOM, rubber, AECM

\begin{abstract}
Abstrak: Penelitian ini bertujuan mengetahui hubungan integrasi dan asimetri antara harga karet TSR20 di pasar Indonesia, SICOM dan New York. Ruang lingkup penelitian ini menggunakan metode Asymmetric Error Corection Model (AECM). Analisis asimetri yang dilakukan merupakan analisis asimetri yang disebabkan perbedaan respon peyesuaian dari segi kecepatan (Speed adjusment). Data yang digunakan merupakan data time series bulanan dari tahun 2010 sampai dengan tahun 2016. Hasil penelitian menunjukan bahwa semua pasar telah terintegrasi. Hubungan yang terjadi adalah pasar SICOM memengaruhi pasar Indonesia, Pasar SICOM dan Pasar New York serta pasar Indonesia dengan pasar New York sama-sama saling memengaruhi. Sedangkan untuk hubungan asimetri terlihat bahwa SICOM dengan pasar Indonesia terjadi hubungan asimetri dalam jangka pendek namun dlam jangka panjang simetri. Sedangkan hubungan antara pasar Indonesia dan pasar New York terjadi hubungan simetri dalam jangka pendek, tetapi jangka panjang tidak simetri. Sementara itu hubunga yang terjadi antara pasar SICOM dan pasar New York simetri baik dalam jangka pendek maupun dalam Jangka panjang. Rekomendasi penelitian selanjutnya, selain melihat harga di pasar SICOM dan Amerika Serikat penting untuk melihat integrasi harga di pasar China. Pasar Cina belakangan ini menjadi pasar yang banyak meng import karet alam selain Amerika Serikat dan Jepang.
\end{abstract}

Kata kunci: TSR20, asimetri, SICOM, karet, AECM

\footnotetext{
${ }^{1}$ Alamat Korespondensi:

Email: andisuryadi.as@gmail.com
} 


\section{PENDAHULUAN}

Karet alam merupakan komoditi penting, karena peran karet alam sebagai bahan baku utama untuk berbagai industri seperti industri otomotif dan industri kesehatan (Herath et al. 2012). Rata-rata pertumbuhan industri otomotifdi Indonesia dari tahun 2011 sampai tahun 2016 sebesar 4,40\% pertahun (Gaikindo, 2017). Sehingga dengan tumbuhnya industri otomotif mendorong peningkatan permintaan TSR20 (Darmawan et al. 2012; Erni et al. 2012).

Indonesia sampai saat ini merupakan produsen karet alam terbesar kedua setelah Thailand. Walaupun, luas areal perkebunan karet Indonesia lebih luas bila dibandingkan dengan perkebunan karet Thailand. Selama beberapa tahun terakhir, produksi karet Indonesia cenderung mengalami peningkatan. Produksi tanaman karet Indonesia pada tahun 2005 mencapai 2.270 .891 ton dan meningkat sebesar $42,3 \%$ pada 2015 menjadi 3.231.825 ton. Berdasarkan Gambar 1, dapat diketahui bahwa pada tahun 2014 produksi karet alam sebesar 3,606 juta ton dan sebesar $72,75 \%$ diekspor keluar negeri dengan 91,55\% total ekspor dalam bentuk TSR20. Karet TSR20 merupakan komoditas ekspor penting dengann kode HS 4001222000. Rendahnya konsumsi karet TSR20 didalam negeri, menyebabkan pasar TSR20 Indonesia sangat tergantung kepada pasar TSR20 Dunia. Tergantungnya pasar TSR20 Indonesia terhadap pasar TSR20 Dunia mengindikasikan harga karet Indonesia dipengaruhi perubahan harga di pasar Dunia.

Indonesia dan Thailand merupakan produsen karet alam yang memiliki peran penting bagi Dunia. Indonesia dan Thailand pada tahun 2013 mengekspor $75 \%$ kebutuhan karet dunia. Karet yang diproduksi di kedua Negara ini, di ekspor keberbagai negara dengan importir utama adalah China dan Amerika Serikat. Dari volume ekspor tersebut Indonesia sebagian besar mengekspor dalam bentuk TSR20 sehingga untuk karet TSR20 Indonesia merupakan Negara eksportir terbesar. Rincian ekspor karet TSR20 dapat dilihat pada Gambar 2 yang menunjukkan bahwa Indonesia merupakan Negara eksportir terbesar karet TSR20. Sebagai Negara produsen terpenting didalam pasar perdagangan TSR20 dunia, total ekspor Indonesia dalam bentuk TSR20 baru dapat disamai dengan total ekspor dari Thailand dan Malaysia.

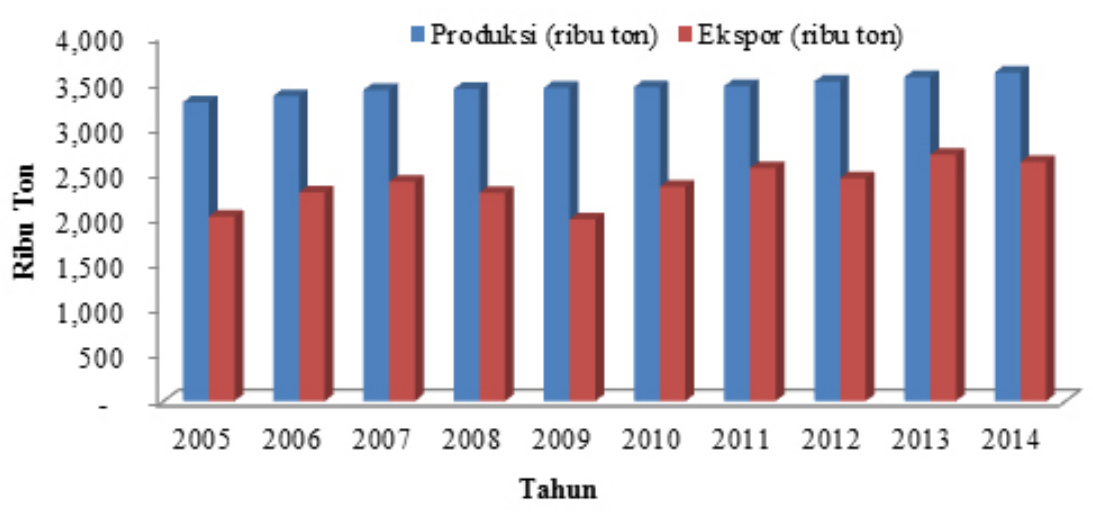

Gambar 1. Produksi karet alam Indonesia tahun 2005-2015 (ton) (Direktorat Jendral Perkebunan, 2016)

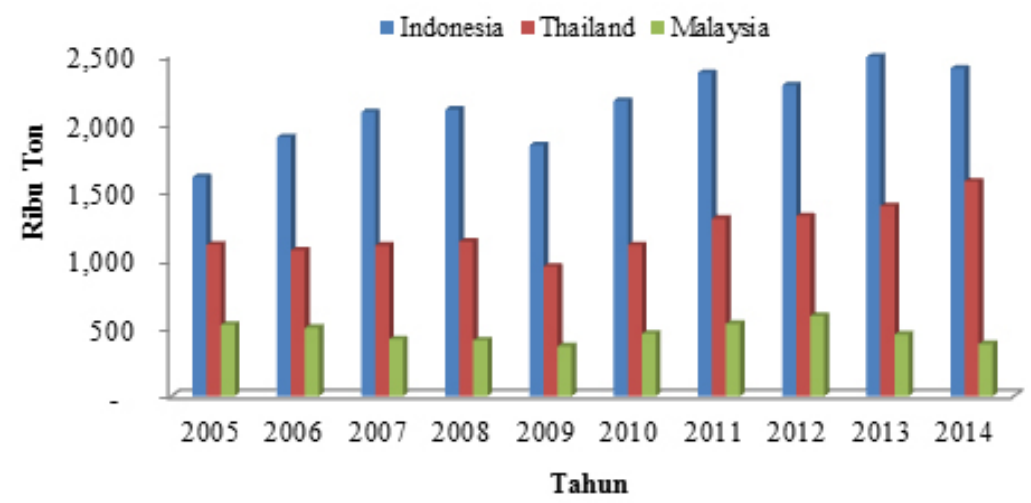

Gambar 2. Volume ekspor karet TSR20 dari Negara-negara eksportir utama (Statistik Indonesia (2007, 2009, 2011, 2014, dan 2015); Statistik Thailand (2016) dan Statistik Malaysia (2016) (diolah)). 
Pada kenyataannya sampai sekarang mekanisme perdagangan karet alam Indonesia masih bertumpu pada perdagangan di pasar fisik dengan mekanisme penetapan harga karet alam Indonesia dengan kecenderungan mengacu pada harga karet yang terbentuk di Singapore Commodity Exchange (SICOM) (Fitrianti, 2009). Selain itu sampai saat ini pasar utama karet TSR20 Indonesia adalah Amerika Serikat, dengan pangsa pasar sebesar $24,21 \%$ dari total ekspor karet TSR20 pada tahun 2015 (Statistik Karet Indonesia, 2015). Oleh karena itu, penting untuk mengetahui integrasi dan asimetri harga antara Indonesia, SICOM, dan Amerika Serikat. Analisis asimetri yang dilakukan didalam penelitian ini, dibatasi hanya asimetri yang disebabkan perbedaan respon peyesuaian dari segi kecepatan (speed adjusment). Sedangkan data yang digunakan merupakan data bulanan dari tahun 2010 sampai tahun 2016.

Keterpaduan antar pasar pada umumnya dikaitkan dengan integrasi harga antar pasar (Ravallion, 1986). Integrasi pasar terjadi apabila terdapat aktifitas perdagangn antara dua atau lebih pasar-pasar yang terpisah secara spasial, kemudian harga di suatu pasar berhubungan dengan satu atau lebih pasar-pasar lainnya. Dalam hal ini harga di suatu pasar secara parsial atau secara total ditransmisikan kepasar-pasar lain, baik dalamjangkapendekmaupunjangkapanjang (Muwanga dan Snyder, 1997). Jika harga terintegrasi dengan baik maka harga di kedua pasar akan di transmisikan secara sempurna (Fazaria et al. 2016). Perubahan yang terjadi disisi permintaan dan penawaran di salah satu pasar akan memengaruhi perdaganan dan harga jual di pasar lainnya (Rapsomanikis et al. 2003). Integrasi pasar akan tercapai jika terdapat informasi pasar yang memadai dan disalurkan dengan cepat kepasar lain, sehingga partisipan yang terlibat memperoleh informasi yang sama (Fadhla et al. 2008). Hubungan satu harga antara pasar yang terpisah secara geografis untuk komoditas yang sama dapat dianalisa menggunakan integrasi pasar spasial (Tomek dan Robinson, 1990)

Penelitian untuk integrasi harga komoditas karet telah dilakukan oleh Fitrianti (2009), Putra (2012), Malik et al. (2013), dan Purnomowati et al. (2015). Fitrianti (2009) melakukan penelitian tentang integrasi harga karet alam Indonesia dengan harga karet alam di pasar berjangka dengan menggunakan data bulanan dari tahun 2000-2009. Prosedur yang digunakan adalah dengan menggunakan analisis VAR, hasil yang didapat bahwa pasar fisik Indonesia terintegrasi dengan pasar berjangka dunia namun tidak ditransmisikan secara langsung karena adanya lag (waktu) penyesuaian. Putra (2012) dengan menggunakan model penyesuaian parsial mengungkapkan bahwa baik dalam jangka pendek maupun jangka panjang harga di karet Internasional berpengaruh negatif dan signifikan terhadap perubahan harga di Indonesia. Malik (2013) dengan menggunakan model VECM mengungkapkan bahwa integrasi yang terjadi antara pasar Singapura dan pasar lelang di Provinsi Jambi tidak terintegrasi secara sempurna. Sementara Purnomowati et al. (2015) melakukan penelitian tentang integrasi pasar karet Indonesia dengan pasar karet Internasional, hasil penelitian yang diperoleh bahwa harga karet Indonesia terintegrasi baik dalam jangka panjang maupun dalam jangka pendek hanya dengan pasar Singapura.

Tujuan dari penelitian ini adalah untuk menganalisis keterkaitan antara TSRI, TSRS dan TSRNY dan Menganalisis hubungan asimetri TSRI,TSRS dan TSRNY.

\section{METODE PENELITIAN}

Penelitian ini menggunakan data skunder yaitu data time series bulanan dengna periode Januari 2010 sampai dengan September 2016. Data sekunder diperoleh dari Badan Pengawas Perdagang Berjangka Komoditi (Bappebti) berupa data harga TSR20 fisik palembang, Pasarberjangka singapura(SICOM) berupa data TSR20, UNCTADSTAT berupa data TSR20 New York, Index Mundi berupa data produksi karet dunia, konsumsi karet dunia. Direktorat Jendral Perkebunan (Dirjenbun) berupa data produksi karet, Bank Indonesia (BI) berupa data nilai tukar rupiah terhadap dolar Amerika Serikat dan inflasi. Data harga TSR20 Indonesia merupakan harga fisik (spot price) Palembang. Data-data tersebut digunakan sebagai variabel dalam penelitian ini dapat di lihat pada Tabel 1.

Metode analisis yang digunakan didalam penelitian ini adalah metode kuantitatif. Pengolahan data kuantitatif menggunakan eviews 8. Adapun beberapa analisis data yang digunakan adalah analisis Integrasi pasar dan transmisi harga TSR20 Indonesia, TSR20 SICOM dan TSR20 New York menggunakan Asymetri Error Correction Model (AECM). 
Tabel 1. Variabel - variabel yang dipakai dalam penelitian

\begin{tabular}{llll}
\hline Nama Variable & Simbol & Satuan & \multicolumn{1}{c}{ Sumber } \\
\hline Harga Karet TSR20 Indonesia & TSRI & $\mathrm{Rp} / \mathrm{Kg}$ & Bappebti \\
Harga Karet TSR20 SICOM & TSRS & Rp/Kg & SICOM \\
Harga Karet TSR20 SICOM & TSRNY & Rp/Kg & UNCTAD \\
\hline
\end{tabular}

Sebelum menganalisis transmisi harga dengan menggunakan model AECM perlu dilakukan beberapa tahapan yaitu uji stasioneritas data, pengujian lag optimum, uji kointegrasi, dan uji kausalitas granger. Uji stasioner digunakan untuk mengetahui kestasioneran data dan menghindari dari masalah spurious regression (Asmarantaka, 2012). Penentuan jumlah lag yang digunakan dalam model dapat memanfaatkan beberapa informasi, yaitu dengan Akaike Information Criterion (AIC), Schwarz Information Criterion (SIC), dan Hannan-Quinn Criterion (HQ). Dalam penelitian ini kriteria yang digunakan adalah kriteria yang memiliki lag terkecil. Uji kointegrasi bertujuan untuk menentukan apakah variabel-variabel yang tidak stasioner, mengalami kointegrasi atau tidak. Dua atau lebih variabel yang dinyatakan berkointegrasi berarti memiliki hubungan atau keseimbangan jangka panjang (long run equilibrium). Selanjutnya, untuk mengetahui adanya kointegrasi antara variabel-variabel dapat dilakukan melalui dua uji statistik, yaitu trace test $\left(\lambda_{\text {trace }}(\tau)\right)$ dan maximum eigenvalue test $\left(\lambda_{\max }\right)$. Setelah diketahui terdapat hubungan kointegrasi maka dilakukan uji kausalitas yang bertujuan untuk memastikanarahhubungan sebab-akibatantara variablevariabel yang diuji. Pada penelitian ini menggunakan uji kuasalitas Engle and Granger karena dapat digunakan pada variabel-variabel yang terkointegrasi. Pengujian dilakukan untuk melihat hubungan antar variabel apakah causality yang terbentuk dalam dua arah (sisi permintaan dan penawaran) atau hanya satu arah saja.

Setelah diketahui arah hubungan, analisis berikutnya yang dilakukan di dalam pengujian transmisi dan asimetri harga TSR20 Indonesia terhadap TSR20 SICOM dan TSR20 New York menggunakan model ECM. Model ECM yang digunakan adalah sebagai berikut:
Pada saat harga TSR20 SICOM memengaruhi TSR20 Indonesia

$$
\begin{aligned}
\Delta T S R I_{t}= & \alpha_{0}+\sum_{t-1}^{n} \beta^{-} \Delta \text { TSRI }_{t-1}^{-}+\sum_{t-1}^{n} \beta^{-} \Delta \text { TSRS }_{t}^{-} \\
& +\sum_{t-1}^{n} \beta^{-} \Delta \text { TSRS }_{t-1}^{-}+e c t_{t-1}^{-}+\sum_{t-1}^{n} \beta^{+} \Delta \text { TSRL }_{t-1}^{+} \\
& +\sum_{t-1}^{n} \beta^{+} \Delta \mathrm{TSRS}_{t}^{+}+\sum_{t-1}^{n} \beta^{+} \Delta \mathrm{TSRS}_{t-1}^{+}+e c t_{t-1}^{+}+\varepsilon_{t}
\end{aligned}
$$

Pada saat harga TSR20 New York memengaruhi TSR20 Indonesia

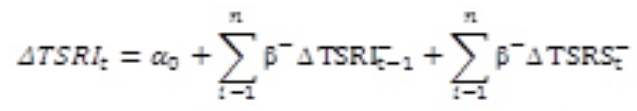

$$
\begin{aligned}
& +\sum_{i=1}^{n} \beta^{-} \Delta \mathrm{TSRS}_{t-1}^{-1}+e c t_{:-1}^{-}+\sum_{i=1}^{n} \beta^{+} \Delta \mathrm{TSR}_{i-1}^{+} \\
& +\sum_{t-1}^{n} \beta^{+} \Delta \operatorname{TSRS}_{t}^{+}+\sum_{t-1}^{n} \beta^{+} \Delta \mathrm{TSRS}_{t-1}^{+}+e c t_{t-1}^{+}+\varepsilon_{t}
\end{aligned}
$$

Pada saat harga TSR20 Indonesia memengaruhi TSR20 New York

$$
\begin{aligned}
& \Delta T S R N Y_{t}=\alpha_{0}+\sum_{i=1}^{n} \beta^{-} \triangle \text { TSRNY }_{t-1}^{-1}+\sum_{i=1}^{n} \beta^{-} \Delta \text { TSRI }_{\tau}^{-} \\
& +\sum_{i=1}^{n} \beta^{-} \Delta \mathrm{TSRI}_{:-1}^{-}+e c t_{:-1}^{-}+\sum_{:-1}^{n} \beta^{+} \Delta \operatorname{TSRNY} \mathrm{T}_{-1}^{+1} \\
& +\sum_{t=1}^{n} \beta^{+} \Delta \operatorname{TSR}_{i}^{+}+\sum_{t=1}^{n} \beta^{+} \Delta \operatorname{TSRI}_{t-1}^{+}+e c t_{t-1}^{+}+\varepsilon_{t}
\end{aligned}
$$

Keterangan: TSRI (harga karet TSR20 Indonesia Periode Ke-t (Rp/ton)); TSRI t-1 $_{\text {(harga karet TSR20 }}$ Indonesia periode sebelumnya (Rp/ton)); TSRS $_{t}$ (harga karet TSR20 SICOM periode Ke-t (Rp/ton)); TSRS $_{\mathrm{t}-1}$ (harga karet TSR20 SICOM periode sebelumnya (Rp/ton)); TSRNY (harga karet TSR20 New York periode Ke-t (Rp/ton)); TSRNY ${ }_{\mathrm{t}-1}$ ( harga karet TSR20 New York periode sebelumnya (Rp/ton)); ect ${ }_{i t}$ (error correction term). 
Untuk membuktikan adanya transmisi harga yang asimetri pada harga TSR20 SICOM dengan TSR20 Indonesia, pengujian hipotesis dilakukan dengan menggunakan F-test (uji wald). Hipotesis dilakukan dengan menggunakan F-test (uji wald).

$\mathrm{H}_{0}: \sum_{i=1}^{p} \beta^{-}=\sum_{i=1}^{p} \beta^{+} ;$simetris dalam jangka pendek

$\mathrm{H}_{1}: \sum_{i=1}^{p} \beta^{-} \neq \sum_{i=1}^{p} \beta^{+}$; tidak simetris dalam jangka pendek

$\mathrm{H}_{0}:$ ect $_{i t}{ }^{-}=e c t_{i t}{ }^{+} \quad ;$ simetris dalam jangka panjang

$\mathrm{H}_{1}$ : ect ${ }_{i t^{-}} \neq e c t_{i t^{+}}$; tidak simetris dalam jangka panjang

Penelitian ini didasarkan dari kerangka pemikiran bahwa suatu pasar yang menganut Law of One Price (LOP) maka akan terjadi transmisi harga yang simetris, sehingga apabila harga pada suatu pasar mengalami perubahan akan ditransmisikan secara sempurna pada pasar lainnya. Harga merupakan salah satu indikator utama yang dapat mencerminkan tingkat efisiensi suatu pasar. Transmisi harga dan tingkat integrasi pasar dapat dijadikan indikasi efisiensi yang terbentuk antar dua pasar yang saling berintegrasi, baik secara vertikal maupun secara spasial (Mayer dan von Cramon-Taubadel, 2004). Namun market power, akses informasi serta faktor lain yang menghambat menyebabkan transmisi harga yang tidak sempurna
(Asmarantaka, 2012). Berdasarkan pandangan tersebut untuk mengetahui perubahan harga karet TSR20 di Indonesia, perlu diteliti integrasi harga TSR20 dengan Integrasi TSR20 di bursa berjangka Singapura (SICOM) dan pasar konsumen yang terletak di pasar New York.

Kerangka pemikiran ini menggambarkan integrasi harga antara pasar yang memperjual belikan komoditi TSR20. Didalam kerangka penelitian ini, ingin dilihat integrasi harga antara TSR20 Indonesia, TSR20 bursa berjangka dunia (SICOM) dan pasar Konsumsi (New York) (Gambar 3).

\section{HASIL}

\section{Integrasi Harga TSR20 Indonesia, SICOM dan New York}

Berdasarkan Tabel 2 terlihat bahwa terdapat hubungan kointegrasi antara variabel harga TSRI dengan TSRS, TSRI dengan TSRNY dan TSRNY dengan TSRS. Hubungan kointegrasi ini menggambarkan bahwa terdapat hubungan antara ketiga pasar. Untuk mengetahui arah hubungan integrasi ini dilakukan uji granger seperti terlihat pada Tabel 3.

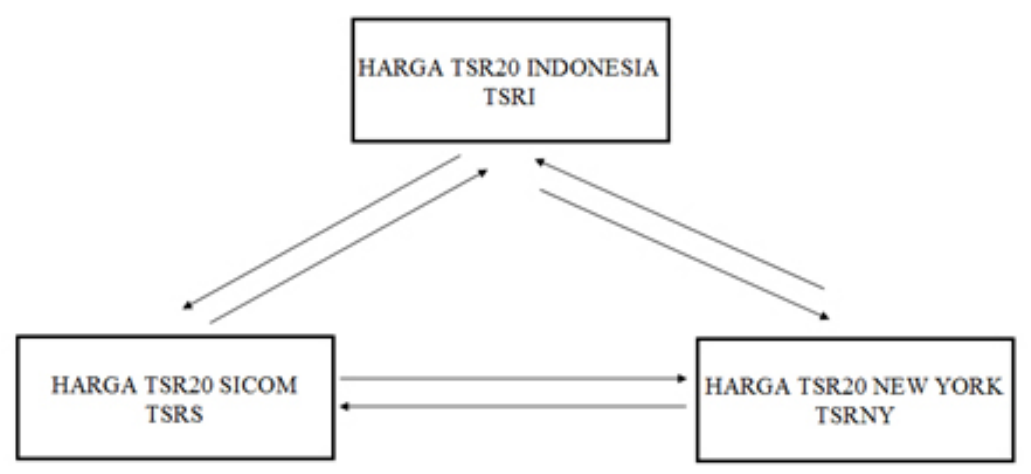

Gambar 3. Kerangka pemikiran penelitian

Tabel 2. Hasil uji kointegrasi pada data harga TRS20

\begin{tabular}{|c|c|c|c|c|c|}
\hline \multirow{2}{*}{ Model } & Hypothesized & \multirow{2}{*}{ Eigenvalue } & Trace & 0.05 & \multirow{2}{*}{ Prob.** } \\
\hline & No. of $\mathrm{CE}(\mathrm{s})$ & & Statistic & Critical Value & \\
\hline \multirow[t]{2}{*}{ TSRI dan TSRS } & None ** & 0.237 & 25.758 & 18.398 & 0.004 \\
\hline & At most $1 * *$ & 0.113 & 7.878 & 3.841 & 0.005 \\
\hline \multirow[t]{2}{*}{ TSRI dan TSRNY } & None $* *$ & 0.273 & 21.424 & 18.398 & 0.018 \\
\hline & At most 1 & 0.015 & 0.990 & 3.841 & 0.320 \\
\hline \multirow{2}{*}{$\begin{array}{l}\text { TSRNY dan } \\
\text { TSRS }\end{array}$} & None $* *$ & 0.397 & 34.823 & 15.495 & 0.000 \\
\hline & At most 1 & 0.030 & 1.982 & 3.841 & 0.159 \\
\hline
\end{tabular}

** signifikan pada tarah nyata $5 \%$ 
Tabel 3. Hasil Uji Kausalitas dengan Metode Granger Test antara harga TSR20 Indonesia, SICOM dan New York

\begin{tabular}{lcccc}
\hline \multirow{2}{*}{ Janis Pasar } & Jumlah & Hubungan 1 & Hubungan 2 & \multirow{2}{*}{ Hasil Kausalitas } \\
\cline { 2 - 4 } & Lag & $\mathrm{H} 0, \pi_{1}=0$ & $\mathrm{H} 0, \pi_{2}=0$ & \\
\hline TSRI dan TSRS & 1 & $4,414^{\mathrm{a}}$ & 2,294 & Hubugan Searah \\
& & $(0,038)^{\mathrm{b}}$ & 0,133 & (SICOM $\rightarrow$ Indonesia) \\
TSRNY dan TSRI & 2 & 9,422 & 4,604 & Hubungan dua arah \\
& & 0,000 & 0,012 & TSRNY $\leftrightarrow$ TSRI \\
TSRS danTSRNY & 2 & 3,460 & 7,040 & Hubungan dua arah \\
& & 0,036 & 0,001 & TSRS $\leftrightarrow$ TSRNY \\
\hline
\end{tabular}

Keterangan: $a=f-$ statistic, $b=$ nilai probabilitas

Analisis Causality Granger

Berdasarkan Tabel 3 menunjukkan bahwa terjadi hubungan searah antara harga TSR20 Indonesia dengan harga TSR20 SICOM. Sehingga dapat diketahui bahwa harga TSR20 Indonesia dipengaruhi oleh harga TSR20 SICOM. Hal ini sesuai dengan yang diungkapkan oleh Fitrianti (2009) bahwa harga karet TSR20 Indonesia dipengaruhi oleh harga yang terbentuk di bursa SICOM.

Sedangkan untuk pasar Indonesia dengan pasar New York terjadi hubungan saling memengaruhi antara kedua pasar. Hal ini dapat terjadi karena pasar New York merupakan pasar tujuan ekspor utama untuk komoditi TSRI dan sebaliknya untuk Indonesia merupakan eksportir utama dalam memenuhi kebutuhan karet TSRNY. Sehingga masing-masing perubahan harga di antara kedua pasar tersebut akan memengaruhi pasar lainnya.

Sementara pada pasar TSRS dan TSRNY memiliki hubungan dua arah. Hubungan ini dapat terjadi karena New York dari sisi perekonomian merupakan Negara dengan perekonomian besar sehingga perubahan yang terjadi akan memengaruhi pasar-pasar lainnya, serta Negara ini merupakan salah satu Negara konsumsi karet TSR20 terbesar sehingga perubahan harga di pasar ini akan memengaruhi pasar SICOM. Namun untuk pasar SICOM dapat memengaruhi harga New York karena posisi strategisnya. Pasar SICOM berada di kawasan Negara-negara utama produsen karet alam. Dengan posisi tersebut mengakibatkan, pasar SICOM menjadi pasar acuan terutama untuk komoditi karet TSR20. Fitrianti (2009) mengungkapkan pula bahwa pasar SICOM merupakan pasar acuan didalam perdagangn karet jenis TSR20 di dunia.

\section{Analisis Asymetric Error Correction Model (AECM)}

Hasil estimasi model pada Tabel 4 dapat dilihat bahwa untuk trasmisi harga dalam jangka pendek, secara deskriptif terjadi perbedaan respon harga karet TSR20 Indonesia baik pada saat shock positif maupun pada saat shock negatif pada setiap variabel independentnya. Untuk variabel harga TSRS pada periode $t$, dengan melihat koefisien $\Delta \mathrm{TSRSt}+$ dan $\Delta \mathrm{TSRSt}$ - menunjukan bahwaperubahankenaikanhargaditransmisikanberbeda dari penurunan harganya. Sedangkan untuk periode t-1 tidak berpengaruh nyata, artinya bahwa perubahan harga pada periode t-1 karet TSRS tidak memengaruhi harga karet TSR20 Indonesia. Implikasi dari hal ini adalah apabila manajemen perusahaan melakukan penyesuaian produksi, inventori dan pemasaran maka harus dilakukan pada periode yang sama. Sedangkan dalam jangka panjang terlihat dari variable ECT. Variable ECT + berpengaruh nyata, artinya apabila terjadi penyimpangan (ketika harga TSRS turun tidak diikuti dengan turunnya harga TSRI) maka setelah 3 bulan harga karet TSRI akan ikut turun juga. Namun apabila terjadi kenaiakan harga karet TSRS, harga TSRI tidak akan pernah naik menyesuaikan kenaiakan harga tersebut.

Hasil estimasi model pada Tabel 5 dapat dilihat bahwa untuk trasmisi harga dalam jangka pendek, secara deskriptif terjadi perbedaan respon harga karet TSR20 New York dan Indonesia baik pada saat shock positif maupun pada saat shock negatif pada setiap variabel independennya. Ketika harga TSRNY memengaruhi TSRI, variabel harga TSRNY pada periode $\mathrm{t}$, dengan melihat koefisien $\triangle \mathrm{TSRNYt+}$ dan $\triangle$ TSRNYt- menunjukan bahwa perubahan kenaikan harga ditransmisikan berbeda dari penurunan harganya. Sedangkan untuk periode t-1 tidak berpengaruh nyata, artinya bahwa perubahan harga pada periode t-1 karet TSRNY tidak memengaruhi 
harga karet TSR20 Indonesia. Implikasi dari hal ini adalah apabila manajemen perusahaan melakukan penyesuaian produksi, inventori dan pemasaran maka harus dilakukan pada periode yang sama. Sedangkan dalam jangka panjang terlihat dari variabel ECT. Variabel ECT + berpengaruh nyata, artinya apabila terjadi penyimpangan (ketika harga TSRS turun tidak diikuti dengan turunnya harga TSRI) maka setelah 5 bulan harga karet TSRI akan ikut turun juga. Namun apabila terjadi kenaiakan harga karet TSRS, harga TSRI tidak akan pernah naik menyesuaikan kenaiakan harga tersebut.

Sedangkan ketika harga TSRI memepengaruhi TSRNY variabel harga TSRNY pada periode t, dengan melihat koefisien $\Delta$ TSRIt+ dan $\Delta$ TSRIt- menunjukan bahwa perubahan kenaikan harga ditransmisikan berbeda dari penurunan harganya. Sedangkan untuk periode t-1 tidak berpengaruh nyata, artinya bahwa perubahan harga pada periode $\mathrm{t}-1$ karet TSRNI tidak memengaruhi harga karet TSRNY. Sedangkan dalam jangka panjang terlihat dari variable ECT. Variabel ECT + berpengaruh nyata, artinya apabila terjadi penuruan harga di pasar TSRI maka harga di pasar TSRNY tidak akan ikut menyesuaikan turun.
Tabel 4. Hasil estimasi model AECM data bulanan dari tahun 2010 sampai tahun 2016 TSRI dengan TSRS

\begin{tabular}{|c|c|c|}
\hline \multirow{2}{*}{ Variabel } & \multicolumn{2}{|c|}{$\mathrm{SICOM} \rightarrow$ Indonesia } \\
\hline & Koefisien & Prob. \\
\hline Konstanta & 150,099 & 0,373 \\
\hline$\Delta \mathrm{TSRS}_{\mathrm{t}}^{+}$ & $0,954 *$ & 0,000 \\
\hline$\Delta \mathrm{TSRS}_{\mathrm{t}}$ & $1,048^{*}$ & 0,000 \\
\hline$\Delta \mathrm{TSRS}_{\mathrm{t}-1}$ & 0,238 & 0,199 \\
\hline$\Delta \mathrm{TSRS}_{-\mathrm{t}-1}$ & 0,063 & 0,778 \\
\hline$\Delta \operatorname{TSRI}_{t^{t-1}}$ & $-0,216$ & 0,251 \\
\hline$\Delta \operatorname{TSRI}_{-\mathrm{t}-1}^{+}$ & $-0,106$ & 0,614 \\
\hline$\Delta \mathrm{ECT}_{\mathrm{t}-1}$ & $-0,219$ & 0,085 \\
\hline$\Delta \mathrm{ECT}_{\mathrm{t}-1}^{+}$ & $-0,022$ & 0,873 \\
\hline R-squäred & 0,913 & \\
\hline Adjusted R-squared & 0,904 & \\
\hline F-statistic & 9,7054 & \\
\hline DW- Stat & 1,967 & \\
\hline
\end{tabular}

Keterangan: *nyata pada alfa $1 \%$,**nyata pada alfa $5 \%$, $* * * *$ nyata pada alfa $10 \%$.

Tabel 5. Hasil estimasi model AECM data bulanan dari tahun 2010 sampai tahun 2016 TSRI dengan NY

\begin{tabular}{|c|c|c|c|c|}
\hline \multirow{2}{*}{ Variabel } & \multicolumn{2}{|c|}{ New York $\rightarrow$ Indonesia } & \multicolumn{2}{|c|}{ Indonesia $\rightarrow$ New York } \\
\hline & Koefisien & Prob. & Koefisien & Prob. \\
\hline Konstanta & 309,083 & 0,061 & $-319,322$ & 0,127 \\
\hline$\Delta \mathrm{TSRNY}_{\mathrm{t}}^{+}$ & $0,645^{*}$ & 0,000 & - & - \\
\hline$\Delta$ TSRNY $_{\mathrm{t}}$ & $0,799 *$ & 0,000 & - & - \\
\hline$\Delta \mathrm{TSRNY}_{\mathrm{t}-1}$ & $-0,140$ & 0,386 & $-0,003$ & 0,986 \\
\hline$\Delta \mathrm{TSRNY}_{\mathrm{t}-1}$ & 0,187 & 0,251 & 0,174 & 0,343 \\
\hline$\Delta \mathrm{TSRI}_{\mathrm{t}-1}$ & - & - & $1,153^{*}$ & 0,000 \\
\hline$\Delta \mathrm{TSRI}_{\mathrm{t}-1}$ & - & - & $1,232 *$ & 0,000 \\
\hline$\Delta \mathrm{TSRI}_{\mathrm{t}-1}$ & $0,277 * * *$ & 0,057 & $-0,039$ & 0,855 \\
\hline$\Delta \mathrm{TSRI}_{\mathrm{t}-1}$ & $-0,101$ & 0,474 & $-0,284$ & 0,183 \\
\hline$\Delta \mathrm{ECT}_{\mathrm{t}-1}$ & $-0,484 *$ & 0,002 & $0,719^{*}$ & 0,000 \\
\hline$\Delta \mathrm{ECT}_{\mathrm{t}-1}$ & 0,088 & 0,495 & $-0,083$ & 0,620 \\
\hline $\mathrm{R}$-squared & 0,933 & & 0,922 & \\
\hline Adjusted R-squared & 0,926 & & 0,914 & \\
\hline F-statistic & 128,7843 & & 109,6617 & \\
\hline DW-Stat & 2,090 & & 1,971 & \\
\hline
\end{tabular}

Keterangan: *nyata pada alfa $1 \%, * *$ nyata pada alfa $5 \%, * * * *$ nyata pada alfa $10 \%$. 
Berdasarkan hasil estimasi model pada Tabel 6 dapat dilihat bahwa untuk trasmisi harga dalam jangka pendek, secara deskriptif terjadi perbedaan respon harga karet TSR20 SICOM dan New York baik pada saat shock positif maupun pada saat shock negatif pada setiap variabel independennya. Ketika harga TSRS memengaruhi TSRNY, variabel harga TSRS pada periode $t$, dengan melihat koefisien $\Delta$ TSRSt + dan $\triangle$ TSRSt- menunjukan bahwa perubahan kenaikan harga ditransmisikan berbeda dari penurunan harganya. Sedangkan untuk periode t-1 berpengaruh nyata hanya untuk penurunannya sedangkan kenaikan harga tidak terpengaruh, artinya bahwa perubahan harga pada periode t-1 karet TSRS akan memengaruhi TSRNY ketika harga TSRS turun. Namun, ketika naik tidak berpengaruh. Sedangkan dalam jangka panjang dapat dilihat dari variable ECTnya, dalam hal ini ECT+ dan ECT- tidak berpengaruh nyata. Artinya, penyimpangan yang terjadi dalam jangka panjang di pasar TSRS tidak akan memengaruhi pasar TSRNY.

Sedangkan ketika harga TSRNY memengaruhi TSRS, variabel harga TSRNY pada periode $t$, dengan melihat koefisien $\triangle \mathrm{TSRNYt+}$ dan $\triangle \mathrm{TSRNYt-}$ menunjukan bahwa perubahan kenaikan harga ditransmisikan berbeda dari penurunan harganya. Sedangkan untuk periode $\mathrm{t}-1$ dengan melihat koefisien $\triangle \mathrm{TSRNYt}-1+$ dan $\triangle$ TSRNYt-1- menunjukan bahwa perubahan kenaikan harga ditransmisikan berbeda dari penurunan harganya. Pada periode t-1, Ketika harga TSRNY naik akan di ikuti pula dengan kenaikan harga di TSRS namun ketika terjadi penurunan di pasar TSRNY harga di pasar TSRS tidak ikut turun juga. Sedangkan dalam jangka panjang terlihat dari variable ECT. Variable ECT+ dan ECT- tidak berpengaruh nyata, artinya penyimpangan yang terjadi dalam jangka panjang di pasar TSRNY tidak akan memengaruhi pasar TSRS.

Untuk memastikan apakah perbedaan-perbedaan koefisien variabel-variabel TSRI, TSRS danTSRNY signifikan maka dilakukan pengujian dengan menggunakan Wald Test. Hasil pengujian ini kemudian akan menjadi ukuran keidentikan antara koefisien shock positif dan shock negatif jangka pendek dan jangka panjang model asimetris. Tabel 7 merupakan hasil pengujian model asimetris untuk jangka pedek dan pangajang.

Tabel 6. Hasil estimasi model AECM data bulanan dari tahun 2010 sampai tahun 2016 TSRS dengan NY

\begin{tabular}{|c|c|c|c|c|}
\hline \multirow{2}{*}{ Variabel } & \multicolumn{2}{|c|}{ SICOM $\rightarrow$ New York } & \multicolumn{2}{|c|}{ New York $\rightarrow$ SICOM } \\
\hline & Koefisien & Prob. & Koefisien & Prob. \\
\hline Konstanta & 188,067 & 0,508 & 43,323 & 0,825 \\
\hline$\Delta \mathrm{TSRS}_{\mathrm{t}}^{+}$ & $1,025^{*}$ & 0,000 & - & - \\
\hline$\Delta \mathrm{TSRS}_{\mathrm{t}}$ & $1,321^{*}$ & 0,000 & - & - \\
\hline$\Delta \mathrm{TSRS}_{\mathrm{t}-1}$ & 0,167 & 0,462 & $-0,273 * * *$ & 0,059 \\
\hline$\Delta \operatorname{TSRS}_{\mathrm{t}-1}$ & $-0,616^{* *}$ & 0,043 & $0,559^{*}$ & 0,005 \\
\hline$\Delta$ TSRNY $_{\mathrm{t}-1}$ & - & - & $0,408^{*}$ & 0,000 \\
\hline$\Delta \mathrm{TSRNY}_{\mathrm{t}-1}$ & - & - & $0,752^{*}$ & 0,000 \\
\hline$\Delta \mathrm{TSRNY}_{\mathrm{t}-1}$ & $-0,127$ & 0,562 & $0,587^{*}$ & 0,000 \\
\hline$\Delta \mathrm{TSRNY}_{\mathrm{t}-1}$ & 0,384 & 0,116 & $-0,365^{*}$ & 0,024 \\
\hline$\Delta \mathrm{ECT}_{\mathrm{t}-1}$ & $-0,129$ & 0,250 & $-0,006$ & 0,941 \\
\hline$\Delta \mathrm{ECT}_{\mathrm{t}-1}$ & $-0,112$ & 0,271 & 0,009 & 0,895 \\
\hline $\mathrm{R}$-squared & 0,840 & & 0,886 & \\
\hline Adjusted R-squared & 0,823 & & 0,874 & \\
\hline F-statistic & 47,936 & & 70,076 & \\
\hline DW- Stat & 1,981 & & 1,996 & \\
\hline
\end{tabular}

Keterangan: *nyata pada alfa $1 \%,{ }^{* *}$ nyata pada alfa $5 \%,{ }^{* * * *}$ nyata pada alfa $10 \%$. 
Tabel 7. Hasil uji asymetri karet TSR20

\begin{tabular}{|c|c|c|}
\hline Wald Test & & F Statistik \\
\hline \multirow[t]{4}{*}{$\mathrm{TSRS} \rightarrow \mathrm{TSRI}$} & $\mathrm{H} 0: \Delta \mathrm{TSRSt}=\Delta \mathrm{TSRSt}$ & $0,783(0,378)$ \\
\hline & $\mathrm{H} 0: \Delta \mathrm{TSRSt}-1=\Delta \mathrm{TSRSt}-1$ & $0,287(0,593)$ \\
\hline & H0: $\Delta$ TSRIt- $1=\Delta$ TSRIt- 1 & $0,122(0,727)$ \\
\hline & $\mathrm{H} 0: \Delta \mathrm{ECTt}-1=\Delta \mathrm{ECTt}-1$ & $0,817(0,369)$ \\
\hline \multirow[t]{4}{*}{ TSRI $\rightarrow$ TSRNY } & H0: $\Delta$ TSRIt $=\Delta$ TSRIt & $0,286(0,594)$ \\
\hline & H0: $\Delta$ TSRIt- $1=\Delta$ TSRIt- 1 & $0,633(0,428)$ \\
\hline & $\mathrm{H} 0: \Delta \mathrm{TSRNYt}-1=\Delta \mathrm{TSRNYt}-1$ & $0,435(0,511)$ \\
\hline & $\mathrm{H} 0: \Delta \mathrm{ECTt}-1=\Delta \mathrm{ECTt}-1$ & $6,666(0,011)^{* *}$ \\
\hline \multirow[t]{4}{*}{ TSRNY $\rightarrow$ TSRI } & $\mathrm{H} 0: \Delta \mathrm{TSRNYt}=\Delta \mathrm{TSRNYt}$ & $3,220(0,076)$ \\
\hline & $\mathrm{H} 0: \Delta \mathrm{TSRNYt}-1=\Delta \mathrm{TSRNYt}-1$ & $3,454(0,067)$ \\
\hline & H0: $\Delta$ TSRIt- $1=\Delta$ TSRIt- 1 & $2,013(0,1601)$ \\
\hline & $\mathrm{H} 0: \Delta \mathrm{ECTt}-1=\Delta \mathrm{ECTt}-1$ & $5,696(0,001)^{*}$ \\
\hline \multirow[t]{4}{*}{$\mathrm{TSRNY} \rightarrow \mathrm{TSRS}$} & H0: $\Delta \mathrm{TSRNYt}=\Delta \mathrm{TSRNYt}$ & $9,822(0,002)$ \\
\hline & $\mathrm{H} 0: \Delta \mathrm{TSRNYt}-1=\Delta \mathrm{TSRNYt}-1$ & $16,465(0,000)$ \\
\hline & H0: $\Delta$ TSRSt $-1=\Delta$ TSRSt -1 & $9,640(0,002)$ \\
\hline & H0: $\Delta$ ECTt $-1=\Delta$ ECTt -1 & $0,015(0,902)$ \\
\hline \multirow[t]{4}{*}{$\mathrm{TSRS} \rightarrow \mathrm{TSRNY}$} & $\mathrm{H} 0: \Delta \mathrm{TSRSt}=\Delta \mathrm{TSRSt}$ & $1,533(0,219)$ \\
\hline & H0: $\Delta$ TSRSt $-1=\Delta$ TSRSt -1 & $3,270(0,074)$ \\
\hline & $\mathrm{H} 0: \Delta \mathrm{TSRNYt}-1=\Delta \mathrm{TSRNYt}-1$ & $1,838(0,179)$ \\
\hline & H0: $\Delta$ ECTt-1 $=\Delta$ ECTt-1 & $0,009(0,920)$ \\
\hline
\end{tabular}

Keterangan: *nyata pada alfa $1 \%,{ }^{* *}$ nyata pada alfa $5 \%, * * * *$ nyata pada alfa $10 \%$.

Berdasarkan Tabel 7 terlihat bahwa hubungan jangka pendek antara harga TSRS terhadap TSRI memiliki nilai probabilitas yang tidak berpengaruh nyata, artinya bahwa dalam jangka pendek terjadi hubungan simetri. Pada hubungan jangka panjang menunjukan nilai probabilitasnya tidak berpengaruh nyata atau dalam kata lain dalam jangka panjang terjadi hubungan simetri antara harga TSRS terhadap TSRI. Hal ini menunjukan bahwa bila terjadi guncangan harga TSRS dalam jangka pendekguncangan harga akan segera diteruskan langsung ke pasar TSRS dalam periode yang sama. Sedangkan dalam jangka panjang apabila terjadi penyimpangan harga, maka harga yang terbentuk yang terbentuk akan kembali kepada titik keseimbangannya. Hal ini sesuai dengan hasil penelitian yang dilakukan Purnomowati et al. (2015), bahwa harga karet Indonesia terintegrasi baik dalam jangka pendek maupun dalam jangka panjang dengan bursa SICOM. Implikasi manajerial yang dapat diambil adalah apabila terjadi penurunan harga maka manajer operasi segera menurunkan produksinya dan barang yang telah di produksi sebagian dapat disimpan untuk dikeluarkan kembali ketika harga mulai berangsur membaik. Sedangkan ketika harga meningkat manajer operasi dapat meningkatkan produksinya dan dapat mengeluarkan hasil produksinya yang disimpan ketika arga turun.
Hubungan asimetri antara harga TSRI terhadap TSRNY terilhat dari nilai probabilitasnya tidak berpengaruh nyata, artinya terjadi hubungan simetri jangka pendek. Sedangkan untuk hubungan jangka panjang berpengaruh nyata, atau dalam kata lain dalam jangka panjang terjadi hubungan asimetri antara harga TSRNY terhadap TSRI. Hal ini menunjukan bahwa bila terjadi guncangan harga TSRI dalam jangka pendek harga yang terbentuk di pasar TSRNY akan ikut berguncang. Namun dalam jangka panjang harga yang terbentuk di pasar TSRNY tidak akan menyesuaikan harga yang terbentuk di pasar TSRI. Asimetri terjadi diakibatkan oleh adanya market power yang dimiliki pedagang didalam suatu pasar (Mayer dan von Cramon Taubadel, 2002; Serra dan Goodwin, 2002; Peltzman, 2000), biaya transaksi yang tinggi dapat mengakibatkan pula transmisi harga yang asimetri (Zachariasse dan Bunte, 2003).

\section{Implikasi Manajerial}

Implikasi manajerial yang dapat diambil dalam jangka pendek adalah apabila terjadi penurunan harga maka manajer operasi segera menurunkan produksinya dan barang yang telah di produksi sebagian dapat disimpan untuk dikeluarkan kembali ketika harga mulai berangsur 
membaik. Sedangkan ketika harga meningkat manajer operasi dapat meningkatkan produksinya dan dapat mengeluarkan hasil produksinya yang disimpan ketika harga turun. Dalam jangka panjang, pengembangan bisnis perusahaan harus mulai memikirkan untuk membuat pabrik lanjutan pengolahan TSR20 untuk menjadi barang jadi. Hal tersebut pentng untuk dipikirkan karena dalam jangka panjang kerugian yang ditimbulkan karena asimetri harga akan sangat besar.

Sedangkan hubungan jangka pendek antara harga TSRNY terhadap TSRI dapat dilihat dari nilai probabilitasnya tidak berpengaruh nyata, artinya bahwa dalam jangka pendek untuk semua variabel terjadi hubungan simetri. Sementara untuk hubungan jangka panjang menunjukkan nilai probabilitasnya berpengaruh nyata atau dalam kata lain dalam jangka panjang terjadi hubungan asimetri. Hal ini menunjukan bahwa bila terjadi guncangan harga TSRI dalam jangka pendek menyebabkan guncangan harga pula pada pasar TSRNY. Namun dalam jangka panjang perubahan harga TSRI tidak diikuti oleh perubahan hargaTSRNY. Menurut von Cramon-Taubadel (2004) terjadinya peristiwa asimetri disebabkan oleh penyalahgunaan market power. Firdausi (2009) menambahkan, bahwa apabila disuatu pasar terjadi hubungan simetri dalam jangka pendek sedangkan dalam jangka panjang terjadi hubungan simetri diakibatkan oleh penyalahgunaan market power yang dilakukan pedagang perantara.

Pada hubungan jangka pendek antara harga TSRNY terhadap TSRS dapat dilihat dari nilai probabilitasnya berpengaruh nyata, artinya bahwa dalam jangka pendek untuk semua variabel terjadi asimetri. Sementara pada hubungan jangka panjang menunjukan nilai probabilitasnya tidak berpengaruh nyata atau dalam kata lain dalam jangka panjang terjadi hubungan simetri. Hal ini menunjukan bahwa bila terjadi guncangan harga di pasar TSRNY tidak seketika menyebabkan guncangan harga di pasar TSRS, penyesuaian harga akan terbentuk dengan masa penyesuaian kurang dari 2 bulan serta dalam jangka panjang akan kembali kepada keseimbangan harga yang terbentuk di pasar New York di ikuti oleh bursa SICOM.

Sedangkan hubungan jangka pendek antara harga TSRS terhadap TSRNY dapat dilihat dari nilai probabilitasnya tidak berpengaruh nyata, artinya bahwa dalam jangka pendek untuk variabel TSRS pada waktu ke-t terjadi hubungan simetri. Sementara pada hubungan jangka panjang menunjukan nilai probabilitasnya tidak berpengaruh nyata atau dalam kata lain dalam jangka panjang terjadi hubungan simetri. Hal ini menunjukan bahwa bila terjadi guncangan harga jangka panjang maupun dalam jangka pendek akan diteruskan secara simetri oleh pasar New York. Peristiwa ini terjadi karena pasar SICOM merupakan pasar acuan dari harga karet TSR20 (Fitrianti 2009).

\section{KESIMPULAN DAN SARAN}

\section{Kesimpulan}

Dari hasil penelitian ini diketahui bahwa ketiga pasar telah terintegrasi, sedangkan hubungan transmisi harga karet TSR20 yang terjadi antara pasar TSRI, TSRS dan TSRNY yakni, harga TSRI dipengaruhi oleh pasar TSRS dan TSRNY, sedangkan pasar TSRNY dipengaruhi oleh pasar TSRS dan TSRI, sedangkan pasar TSRS hanya di pengaruhi oleh pasar TSRNY. Hubungan asimetri yang terjadi antara ketiga pasar adalah, pasar TSRI terjadi hubungan simetri dalam jangka pendek maupun dalam jangka panjang terhadp TSRS, sedangkan hubungan TSRI degnan TSRNY terjadi hubungan simetri dalam jangka pendek namun dalam jangka panjang terjadi hubungan asimetri. Hubungan asimetri antara TSRS dengan TSRNY terjadi hubungan asimetri dalam jangka pendek namun dalam jangka panjang terjadi hubungan simetri.

\section{Saran}

Untuk Penelitian selanjutnya perlu melihat hubungan integrasi dengan pasar konsumen lainnya seperti Tiongkok dan Jepang. Selain melihat hubungan integrasi harga antara pasar perlu juga diteliti faktorfaktor pembentuk harga, agar faktor-faktor yang memengaruhi perubahan harga diketahui sehingga aspek manajerial dari perubahan harga dapat lebih baik lagi.

\section{DAFTAR PUSTAKA}

Asmarantaka RW. 2009. Bunga Rampai Agribisnis: Seri Pemasaran. Bogor: IPB Press

Darmawan MA, Wiguna W, Marimin, Machfud. 2012. Peningkatan produktifitas karet alam dengan pendekatan green productivity: studi kasus di PT X. Jurnal Teknologi Industri Pertanian 22(2): 98-105. 
Direktoret Jendral Perkebunan. 2007. Statistik Karet Indonesia. Bogor: Badan Pusat Statistik.

Direktoret Jendral Perkebunan. 2015. Statistik Karet Indonesia. Bogor: Badan Pusat Statistik.

Erni N, Maarif MS, Indrasti NS, Machfud, Honggokusumo S. 2012. Model prakiraan harga dan permintaan pada rantai pasok karet spesifikasi teknis menggunakan jaringan syaraf tiruan. Jurnal Al Azhar Indonesia Seri Sains dan Teknologi 1(3): 116-123.

Fazaria DA, Hakim DB, Sahara. 2016. Analisis integrasi lada di pasar domestik dan internasional. Buletin Ilmiah Litbang Perdagangan 10 (2):225-242.

Fitrianti W. 2009. Analisis integrasi pasar karet alam antara pasar fisik di Indonesia dengan pasar berjangka dunia [tesis]. Bogor: Institut Pertanian Bogor

Goodwin BK, Holt MT. Asymmetry adjustment and price transmission in the US beef sectors. American Journal of Agricultural Economics 79: 630-637.

Herath K, Samita S, Wijesuriya W. 2012. Identification of common trends in prices, demand and supply of natural rubber: an approach using dynamic factor model. Tropical Agricultural Research 24(1): $\quad 54-70 . \quad$ https://doi.org/10.4038/tar. v24i1.7989.

Malik A, Murdy S, Nainggolan S. 2013. Analisis Integrasi pasar crumb rubber singapura dan pasar lelang karetkabupaten batang hari Provinsi Jambi. Di dalam: Peranan Teknologi dan Kelembagaan Pertanian dalam Mewujudkan Pembangunan Pertanian yang Tangguh dan Berkelanjutan; 2013 November; Pekan Baru, Indonesia. Pakan Baru: Universitas Riau. hlm 254-270
Mayer J, von Cramon-Taubadel S. Asymmetric price transmission: a survey. Journal of Agricultural Economics 55(3): 581-611.

Muwanga GS, Snyder DL. 1997. Market integration and the low of one price: case study of selected feeder cattle market. Economic Research Institute Study Paper 97-11.

Purnomowati HD, Darwanto DH, Widodo S, Hartono S. 2015. Market integration analysis of indonesian natural rubber in the world market. International Journal of Agriculture System 3 (2): 15-27.

Peltzman S. 2000. Prices Rise Faster than they fall. Journal of Politics Economy 108(3): 466-502. https://doi.org/10.1086/262126.

Putra MHI. Determinan permintaan karet Indonesia. Signifikan 1(2): 127-138.

Ravallion M. 1986. Testing market integration. American Journal of Agricultural Economics Association 68(1): 102-109. https://doi. org/10.2307/1241654.

Rapsomanikis G, Hallan D, Comforti P. 2003. Market integrration and price transmission in selected food and cash crop market of developing countries: review and applications. FAO Commodity And Trade Policy Research Working Paper 7: 1-81.

Tomek W, Robinson KL. 1990. Agricultural Product Price. London. Cornel University Press

Zachariasse V, Bunte. 2003. How Are Farmers Faring in the Changing Balance of Power Along the Food Chain?. Conference on Changing Dimension of the Food Economy Exploring the policy Issue, Netherland (NL). 